netta impressione che il Dante di Mazzotta sia entrato per la prima volta a far parte di una costellazione poetica e filosofica, e quindi teologica, che veramente gli si confa e che giustifica il fitto nesso di echi e di tonalità che da sempre sfugge alla lettura critica del poema. Per questo il libro di Mazzotta andrebbe studiato e consultato come un'enciclopedia, attentamente e rigorosamente, perché i suggerimenti e le aperture critiche sono tali che la critica dantesca informata dovrà passarci e misurarcisi.

Ma il libro di Mazzotta è solo in parte un libro su Dante. L'opera s'inserisce facilmente tra le opere critiche contemporanee che fanno luce e rischiarano gli orizzonti del pensiero moderno. La lettura enciclopedica proposta da Mazzotta è anche una proposta critica che attacca i capisaldi su cui si basa il pensiero contemporaneo e ne chiarisce e risolve le contraddizioni, come ad esempio la revisione del rapporto e della funzione epistemologica delle arti liberali e la sua proposta di un sapere totale. Lo studio dimostra come il pensiero critico che fa capo ad una rivalutazione del poetico in chiave teologica riesce a restituire una dimensione critica del testo letterario da sempre offuscata se non del tutto cancellata. Per questo sembra appropriato osservare che con questo studio l'italianistica entra nei grandi dibattiti della critica contemporanea che di solito sono confinati tra Francia e America. Non solo la critica dantistica ma anche quella che si pone il problema dell'identità e funzione del testo letterario deve raccogliere e studiare la proposta presentata dallo studio di Mazzotta per poter meglio ridefinire la direzione futura del pensiero critico e teoretico contemporaneo. A questo punto si dovrebbero ripetere le parole di Gregory Lucente che in occasione di un suo saggio sulla "Teoria letteraria contemporanea negli Stati Uniti" (Lettere Italiane 41.2 [aprile-giugno 1989] 265-93) citava lo studio di Mazzotta su Boccaccio, The World at Play in Boccaccio's Decameron (Princeton UP, 1986) e faceva l'elogio non solo dell'opera, che ricordava come "sicuramente una delle più interessanti degli ultimi anni" (293), ma dell'autore ricordandolo come critico che aveva dato dell'opera di Boccaccio e della sua epoca una lettura che li aveva resi "stimolanti in una maniera mai vista precedentemente" (293). Quindi concludeva assegnandogli il merito di "un intuito critico non comune" (293). Dante's Vision and the Circle of Knowledge convalida assolutamente la valutazione di Lucente e conferma Mazzotta come uno dei più importanti ed originali critici contemporanei.

\title{
MASSIMO VERDICCHIO
}

University of Alberta

Marjorie O'Rourke Boyle. Petrarch's Genius: Pentimento and Prophecy. Berkeley and Los Angeles: U of California P, 1991. Pp. 216.

Marjorie O'Rourke Boyle, herself a theologian, eloquently re-examines Petrarch's poetry and prose, redirecting the focus away from whether or not Petrarch was a sinner, to whether or not Petrarch was a theologian and prophet. This question has been confronted before, but until now always from a literary point of view. As Boyle says in her Epilogue, Petrarch was a theologian who was abandoned "to those scholars who dealt with the ambiguities of life and of language: historians and literary critics. With the historiographical designation of Petrarch as the herald of modernity, his sacred charism was re- 
solutely replaced by secular virtue" (153).

Boyle demonstrates how Petrarch turned to classical inspiration when poetry and theology were seen as equal, and how "this identification of solar Apollo with Christ as 'the true sun and light of the world' was the immediate inspiration for Petrarch's poetics" (33). In Petrarch's coronation speech, citing Virgil, he professes that the poet is prophet. Indeed Apollo in the Aeneid is the one who inspires oracles. For Petrarch, the laurel, the divine bough of Apollo, became the symbol of his vocation as prophet. Boyle points out that it was the laurel, the Apolline bough, not Laura, that appeared to Petrarch on April 6 (for Petrarch Good Friday), 1327. When Petrarch describes himself as entangled in Laura's golden hair, Boyle reveals that "the bonds were symbolized by Laura's hair, in an extension of the metaphor of the Song of Solomon 5:7, which described the lover as netted in the tresses of the beloved. Since golden tresses often vied with solar rays in the medieval poetry derived from an aesthetic of light, her golden locks were also an Apolline symbol of inspiration" (64). Laura's golden hair, Apollo's solar rays, shine divine light on Petrarch's genius. When examining the 366 poems which make up the Rime sparse, Boyle substitutes the notion of Petrarch's God-given but frustrated genius, for the traditionally held concept of oscillation. If Petrarch was crowned as citizen of Rome, then it was his purpose in life to use his God-inspired genius to effect the return to Rome of the papacy and the empire. Petrarch shifts Babylon from the pagan Rome of Revelations to Avignon, and assumes the role of prophet. As Boyle points out, "he assumed a prophetic posture. To the Vergilian ideal of the poet as the Apolline oracle who established the national morality, Petrarch assimilated the scriptural role of the prophet who essayed the same vocation as Yahweh's herald" (89). Petrarch was the Ezekiel, "appointed by the Lord as "a watchman for the house of Israel" (92), who witnesses the captivity in Avignon first hand. Boyle's superb analysis of Petrarch's six oracles of doom in Chapter 3 (The Babylonian Captivity) combines a theological expertise with keen perception of the aging Petrarch's frustration and defeat. The Babylon would be permanent. "It incited the poet to crave death rather than exile, for, with the end of "the sun of righteousness,' Babylon would indeed be 'no light anywhere . . . but only gloom on all sides . . . a night of eternal darkness, I may add, devoid of stars, in which dawn never comes, and where deeds, moreover, are performed in deep and perpetual shadows" (112). If the Babylon is to be perpetual, then it is defeat for Petrarch's God-inspired eloquence. All the images from his six oracles of doom: "The lioness, the ship, the laurel, the fountain, the phoenix, and the wife of his visions, all of which perished ominously, symbolized the failure of his poetry to incite virtue through the knowledge of truth in veiled fiction" (113).

In Chapter 4 (Wounded Lovers) Boyle describes the wounded Petrarch whose Laura/laurel are no longer with him: the Laura with the golden hair, the golden rays which are his sun, are now up there while he is still down here. Petrarch's wounds remain, the wounds he both hated and loved. But Petrarch is not alone with his wounds. With him are the wounded Italian people, with the Babylonian Captivity, and with him is the wounded Christ, the wounds of Christ into which the defeated Petrarch at the end of the Rime sparse hopes to find a mystical repose. Boyle eloquently concludes: "So it was in poetic imitation of the divine passion of an Apolline Christ, suspended on the cross like a psalmist's lyre in Babylon, that Petrarch in his genius invented his books: the prophetic labors of love" (151).

This articulate re-examination of both the prose and poetic works of Petrarch is the most important book to come out in Petrarch studies in many years. It will influence 
significantly the way we read him in the future.

LLOYD HOWARD

University of Victoria

Gian Carlo Garfagnini, ed. Lorenzo de' Medici. Studi. Istituto Nazionale di Studi sul Rinascimento (Studi e Testi 27). Firenze: Olschki, 1992. Pp. xii, 353.

This collection of essays emerged from the great editorial project of the complete letters of Lorenzo de' Medici (il Magnifico). The purpose was to place the letters in a broader context, to enrich our knowledge of Lorenzo by connecting him to his historical, political and literary environment so that the letters would be even more meaningful. The result is a wonderful series of nine papers in English and Italian prepared by two generations of scholars of the Florentine Renaissance which provide deep insight into specific elements of the life, character and times of the magnificent Lorenzo.

Some of these essays provide a broad perspective on Lorenzo, Florence and the Renaissance. Melissa M. Bullard's "Lorenzo de' Medici: Anxiety, Image Making, and Political Reality in the Renaissance," for example, is a splendid study of Renaissance selffashioning, placing Lorenzo in the "theatre culture" of the Renaissance. It is innovative, provocative and important work which offers a profound analysis of the nature of Lorenzo's relationship to his city and other states and his ability to cultivate an image which associated his own personal rule with the success of Florence itself.

Other papers are more specific, dealing with particular aspects of Lorenzo's life. Nicolai Rubinstein applies his unparalleled knowledge of the operation of the Florentine Republican constitution to "Lorenzo de' Medici [and] the Formation of His Statecraft." Paula Clarke discusses the relationship of Lorenzo with Tommaso Soderini; and Christine Shaw investigates Lorenzo's dealing with his kinsman by marriage and condottiere in the employ of Florence Niccold Orsini. War is, obviously, an important element in this paper and the theme of Florence's diplomacy and policy in time of conflict is rehearsed from different perspectives in Humfrey Butter's "Florence, Milan and the Barons' War (1485-1486)" and Michael Mallett's "Diplomacy and War in Later Fifteenth-Century Italy."

Individual significant aspects of foreign policy are carefully studied (with many relevant documents provided in appendices) by Riccardo Fubini in his "In margine all'edizione delle 'Lettere' di Lorenzo de' Medici, I: La visita a Firenze del duca di Milano nel 1471, II: L'ambasciata a Roma di Alamanno Rinuccini nel 1476." Alison Brown addresses Lorenzo's domestic authority, especially his consolidation of power in the city, and offers clear and convincing proof of his use of public funds for his private gain in "Public and Private Interest: Lorenzo, the Monte and the Seventeen Reformers."

Finally, Mario Martelli in "Un caso di 'amphibolatio': la canzone a ballo 'Ragionavasi di sodo" reads the several layers of meaning in Lorenzo's poetry, ranging from obscenity to divine spirituality, to illustrate the complexity of his literary work and the profundity of his thought. Martelli also puts his selection of Lorenzo's poetry into the context of the work of Ficino and Florentine Neoplatonic concepts of love, as well as broader intellectual interests.

Taken together, these nine essays succeed in revealing Lorenzo's character, policies and times. Consequently, they do indeed help in the elucidation of the author of the vol- 